\title{
EDITORIAL
}

\section{O Plano de Classificação de Cargos e as Reivindicações do Funcionalismo}

O andamento, no Congresso Nacional, do projeto de classificação de cargos e revisão dos niveis de remuneração do funcionalismo civil da União sugere, como é natural, algumas considerações que seria oportuno formular antes de que se inicie o processo de implantação definitiva do sistema.

É evidente que o Plano que se consubstancia através do referido projeto, embora resultante de estudos cuidadosos efetuados por técnicos especializados no tratamento dos problemas que envolve, não poderá realizar o milagre de, apenas implantado, corrigir tôdas as injustiças e sanar tôdas as irregularidades que a longa prática de um regime mais ou menos empírico de classificação de cargos permitiu se desenvolvesse.

Será inevitável que a nova estrutura decorrente da racionalização projetada determine numerosas reivindicações de grupos ou indivíduos descontentes com a situação que thes seja acaso reservada na nova sistemática.

Não há dúvida de que grande parte das reivindicações que então se formularão, resultará apenas de-uma defeituosa apreciação do problema, conseqüência da natural tendência de examinar-se a matéria do ponto de vista dos interêsses pessoais. 
Outras reclamações, todavia, se apresentarão inteiramente procedentes, porque a despeito de ter sido a elaboracão do trabalho confiada, como ressaltamos, a uma equipe de técnicos experientes, não seria de justiça presumir-se a sua infalibilidade.

É igualmente verdade, por outro lado, que se o referido plano não tem a virtude de remediar de imediato tôdas as falhas acaso existentes no sistema vigente, representa, todavia, a certeza de que no futuro essas situações não mais se reproduzirão.

Vencida, por conseguinte, essa etapa intermediária de tramitação legislativa do projeto, e tão logo se efetue a implantação do novo regime, as atenções do funcionalismo devem voltar-se para a tarefa de administração corrente do sistema, que.no seu dinamismo oferecerá a oportunidade para a retificação de quaisquer deficiências que por ventura a prática venha a revelar .

É, aliás, essa flexibilidade, característica de todo Plano de Classificação de Cargos que permite o reacerto dos contínuos desajustamentos inevitáveis no funcionamento da complexa máquina burocrática .

Disso se conclui que, convertido em lei o projeto e definitivamente implantado o sistema, não ficará encerrada, para o funcionalismo, a oportunidade de ver satisfeitas as suas reivindicações legítimas, eis que essa maleabilidade, acima ressaltada, permitirá, em qualquer tempo, o reexame das situações isoladas, acaso merecedoras de reparo. 